\title{
Effects of supplemented Sauropus androgynus leaves powder on reproductive traits of Indonesian indigenous hens
}

\author{
H. D. Putranto* and U. Santoso \\ Department of Animal Science, Faculty of Agriculture, Universitas Bengkulu \\ Jalan Raya W. R. Supratman, Kota Bengkulu, Bengkulu Province, Indonesia \\ *Corresponding E-mail: heri_dp@unib.ac.id;
}

Received March 23, 2021; Accepted September 11, 2021

\begin{abstract}
The aim of this study was to analyze of Sauropus androgynus (SA) leaves powder supplementation on kampung hens reproductive traits. Forty kampung hens aged 4-5 months were distributed randomly into 4 treatments with 10 replications. A completely randomized design (CRD) was used as research design. Samples were placed in individual postal-litter system cages. The four groups were fed diets supplemented with $0,4,8$, and $12 \%$ SA leaves powder for 8 weeks, respectively. The supplementation of SA leaves powder affected serum steroid hormone progesterone $(\mathrm{P} 4)$ metabolite $(\mathrm{P}<0.05)$, serum steroid hormone estradiol-17 $\beta$ (E2) metabolite concentration and a number of medium follicles yield significantly $(\mathrm{P}<0.01)$. Concentration levels of serum steroid hormone E2 and P4 metabolites were 1 to 5-fold and 2 to 14-fold higher in supplemented hens than non-supplemented, respectively. In conclusion, supplementation of SA leaves increased serum steroid hormone E2 and P4 metabolite concentration, number, and weight of follicles. The role of precursor contained in SA leaves powder detected on Indonesia kampung hen's reproductive traits.
\end{abstract}

Keywords: Follicle, Kampung hen, Katuk leaves, Reproduction, a steroid hormone

\section{INTRODUCTION}

Kampung chicken (Gallus domesticus) is the most populated indigenous or local chicken in Indonesia and is widely identified as a descendant of red jungle fowls (G. gallus) and green jungle fowls $(G$. varius). They were inhabited by tropical rain forest along the equator (Soenarsih and Hoda, 2019), then domesticated and proliferated by rural communities. These local chickens are common to be found until now in Indonesia because they are relatively easy to raise, do not require large capital and it plays a role in utilizing household waste and agricultural products (Soenarsih and Hoda, 2019; Mariandayani et al.,
2013). This function role is also found in Asia Africa region local chicken (Habteslasie et al., 2019; Teinlek et al., 2018).

A previous study reported kampung hens can produce about 103 eggs/hen/year (Mariandayani et al., 2013). Furthermore, kampung chickens rearing their offsprings after hacting for a certain time, their egg productions reach only about 52 eggs/hen/year. However, when offsprings are separated since hatching, their production could reach 115 eggs/hen/year. This egg production is far below compared to egg production in layers. It is similar to the result of Soenarsih and Hoda (2019) and Mariandayani et al. (2013) which stated productivity of kampung 
chickens in producing meat and eggs is lower compared to the productivity of broilers and layers. Researchers (Soenarsih and Hoda, 2019; Mariandayani et al. 2013) assumed the body weight and body size of kampung chicken which are lighter and smaller than broilers and layers became the main cause of this problem.

Several studies (Santoso, 2018; Putri et al., 2013) have attempted to improve kampung chicken egg productions, including crossbreeding methods, improving feeding material and composition methods, or application of medicinal plants to reveal its reproductive trait potency. One of the potential method to apply in this study woud be the supplementation of medicinal plants.

Medicinal plants have economic value, both in the local community who live in rural areas and modern society who live in urban areas (Hayati et al., 2016). Studies on the role of medicinal plants show that medicinal plants can improve production and reproduction performance (Nurmeiliasari et al., 2020). Medicinal plants have active compounds that play a role in supporting animal productivity and health (Abou -Elkhair et al., 2018; Ding et al., 2017). In Indonesia, Sauropus androgynus (SA) is well known to be used as one of the local medicinal plants.

Supplementation of SA leaves extract or powder as one of medicinal plant has been introduced to broilers (Sulfiar et al., 2020; Letis et al., 2017), layers (Nurmeiliasari et al., 2020; Santoso 2018), and another local chicken called Burgo chicken (Putranto et al., 2012). According to Awaludin et al. (2020) and Hayati et al. (2016) there are 5 unsaturated fatty acid compounds in $S$. androgynus such as octadecanoic acids, 9-eicosyne, 5,8,11-heptadecatrienoic acid methyl ester, 9,12,15-octadecatrienoic acid ethyl ester, and 11,14,17-eicosatrienoic acid methyl ester. Also, one steroid compound is androstan17-one 3-ethyl-3-hydroxy-5alpha (Awaludin et al., 2020; Hayati et al., 2016). Thus, androstan17-one,3-ethyl-3-hydroxy-5 alpha represents 17ketosteroid (precursor) which is an intermediate compound on steroid hormone biosynthesis (Hayati et al., 2016).

Nurmeiliasari et al. (2020) and Santoso (2018) reported supplementation of SA extract in broilers improved the quality of chicken meat and increased egg quality and egg production in layers. As a comparison, in another Indonesia local chicken, Putranto et al. (2012) reported that supplementation of SA extract increased serum steroid hormone estradiol-17 $\beta$ metabolite concentration and the number of follicles in Burgo hens. Concerning SA has a steroid compound mentioned earlier, utilization of this medicinal plant should contribute positive impacts on reproductive traits. However, there is no scientific report about supplementation of SA on kampung hens reproductive traits especially on serum steroid hormone metabolites, lately.

Utilization of SA to improve hens serum steroid hormone estradiol-17 $\beta$ (E2) metabolite concentration and its effect on follicles of Burgo chicken had been reported by previous studies (Putranto et al., 2012). Previous studies reported the presence and role function of steroid hormone E2 metabolite on reproduction is also closely related to the presence and function of steroid hormone progesterone (P4) metabolite, especially their similar effect on ovarium function to produce follicles (Navara 2013; Janczak et al., 2009; Reddy et al., 2006).

Therefore, the purpose of this study was to analyze SA leaves powder supplementation on kampung hens reproductive traits including serum steroid hormones metabolites concentration, follicles yield, and egg productions.

\section{MATERIALS AND METHODS}

The present study was conducted at Com-

Table 1. Sauropus androgynus Leaves Powder Content Analysis Result (\%/100 g)

\begin{tabular}{|c|c|c|}
\hline No & Contents & Percentage (\%) \\
\hline 1 & Water & 9.15 \\
\hline 2 & Ash & 10.2 \\
\hline 3 & Crude Protein & 34.2 \\
\hline 4 & Crude Fat & 2.9 \\
\hline 5 & Crude Fiber & 13.2 \\
\hline 6 & Calcium & 1.03 \\
\hline 7 & Phospor & 0.62 \\
\hline 8 & Gross Energy & $4,307.3$ \\
\hline
\end{tabular}

Gross Energy $=$ unit in $\mathrm{kcal} / \mathrm{kg}$ 
mercial Zone and Animal Laboratory Department of Animal Science Faculty of Agriculture Universitas Bengkulu Indonesia. All procedures and protocols were officially approved for Ethical Clearance number 02/KEH-LPPM/EC/2020 and verified by the Animal Ethical Committee of Universitas Bengkulu.

\section{Sauropus androgynus Leaves Powder Prepa- ration}

Fresh SA leaves were dried under a room temperature for 3 days and continued by drying under the sun for approximately 6 to 8 hours until leaves are completely dry. Dried leaves were mixed and ground using a feed grinder machine until they become ready-to-use powder. The SA leaves powder was homogenized by stirring it evenly and stored using an airtight plastic until it is supplemented in the ration. SA leaves analysis result released by the registered laboratory is presented in Table 1.

\section{Animal, Treatments and Diets}

Forty kampung hens age range from 4 to 5 months were used in this latest study. According to Trisiwi (2017), kampung hen reaches its sexual maturity at about 5 months of age. Based on this reason, we assumed all hens used in this study were classified as pullets in their very early sexual maturity phase. The average of body weight was $1,026.75 \pm 196.18 \mathrm{~g} / \mathrm{hen}$, and all in good health condition.

Hens were placed in individual postal-litter system cage equipped with individual feeding and drinking devices. Prior the research, they were managed for a week of adaptation to intensive rearing system, individual cage, feeding, drinking, and other daily management and research activities such as data collection.

Kampung hens were given experimental diets for 8 weeks. The composition of these diets is presented in Table 2. Diets and drinking water were given ad libitum.

\section{Experimental Procedure and Sample Collec- tion}

Each kampung hen was housed in an individual postal-litter system cage. The size of these cages was $100 \times 100 \times 100 \mathrm{~cm}$ facilitated with feeding and drinking water tools. The cage and the tools were sprayed by disinfectans a week prior the adaptation phase of study.

A completely randomized design (CRD) was used as a research design with 4 treatments of ten replications. The 4 treatments were as follows :

AK0 : kampung hens were given a diet without SA leaves powder (SALP).

AK1 : kampung hens were given a diet with $4 \%$ SALP.

AK2 : kampung hens were given a diet with $8 \%$ SALP.

AK3 : kampung hens were given a diet with $12 \%$ SALP.

The variables measured in this study were the concentration of serum steroid hormone estradiol-17ß (E2) metabolite, serum steroid hormone progesteron $(\mathrm{P} 4)$ metabolite, number and

Table 2. Composition of Diets $(\% / \mathrm{kg})$

\begin{tabular}{clcccc}
\hline No & Feed Contents (\%) & AK0 & AK1 & AK2 & AK3 \\
\hline 1 & Scrumble corn & 42 & 41 & 38 & 36 \\
2 & Layer concentrate & 29 & 29 & 29 & 29 \\
3 & Rice bran & 26.5 & 24 & 23 & 21 \\
4 & Palm oil & 1 & 1 & 1 & 1 \\
5 & SA leaves powder & 0 & 4 & 8 & 12 \\
6 & Mineral mix & 1 & 1 & 1 & 1 \\
7 & Commercial feed additive & 0.5 & 0 & 0 & 0 \\
Total Percentage (\%) & 100 & 100 & 100 & 100 \\
\hline Nutrition Composition & & & & \\
\hline Energy (kcal/kg) & $2,758.4$ & $2,794.5$ & $2,791.3$ & $2,788.2$ \\
Protein (\%) & 17.3 & 17.7 & 18.02 & 17.9 \\
Calcium (\%) & 3.84 & 3.9 & 4.04 & 4.03 \\
Phospor (\%) & 0.6 & 0.57 & 0.57 & 0.55 \\
\hline
\end{tabular}

AK0 = kampung hens were given a diet without $S$. adrogynus leaves powder (SALP); AK1 = kampung hens were given a diet with $4 \%$ SALP; AK2 = kampung hens were given a diet with $8 \%$ SALP; AK3 = kampung hens were given a diet with $12 \%$ SALP 
weight of large follicle yield (LFY), medium follicle yield (MFY), small follicle yield (SFY), and the number of egg production. At 56 days of age, $5 \mathrm{ml}$ of blood samples were collected from randomly 5 hens of each treatment group for serum steroid hormone metabolites measurement. Those hens were then slaughtered and ovary and connective tissue were collected for LFY, MFY and SFY counts. Egg productions were collected daily during 8 weeks of the treatment period.

\section{Serum Steroid Hormones Metabolites Analy-} sis

Serum steroid hormones E2 metabolites and serum steroid hormone P4 metabolites were determined by a combination of Sandwich Enzyme
Immuno Assay (EIA) procedure and Enzim Linked Imonnoflorecsent Assay (ELFA) procedure conducted in Kimia Farma Laboratory, Jakarta Indonesia. At 07:00 in the morning, the amount of $5 \mathrm{ml}$ blood was taken from an artery in the inner part of a wing, saved in a non EDTA tube, kept in a cooler, and sent to the laboratory immediately. The E2 anti-serum mainly crossreacts with E2, estrone-3-sulfate, 16-epiestriol, estrone and estriol at 100, 8.0, 5.3, 3.2, and $1.8 \%$, respectively. Then, $\mathrm{P} 4$ antiserum crossreacts mainly with $\mathrm{P} 4,5 \alpha$-pregnanedione, pregnenolone, 11-deoxycorticosterone, $17 \alpha$ hydroxyprogesterone, and 11 $\alpha$ hydroxyprogesterone at $100,62.2,6.3,3.9,2.3$, and $1.2 \%$, respectively (Putranto et al., 2007;

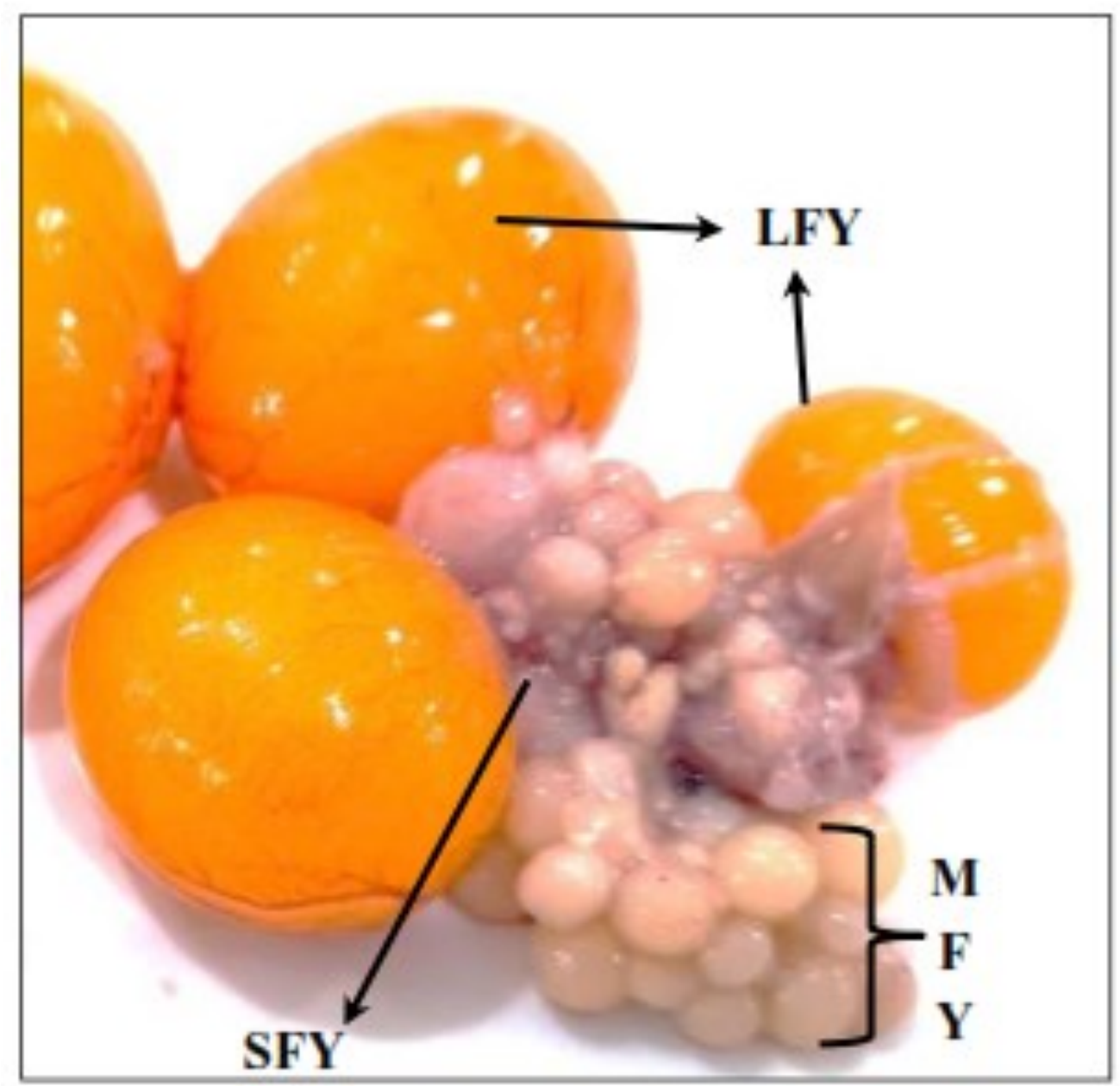

Figure1. Profile of Indonesia Kampung Hen's Follicles (LFY, MFY, and SFY) Who Supplemented by $S$. androgynus Leaves Powder. LFY = Large Follicle Yield, MFY = Medium Follicle Yield, SFY $=$ Small Follicle Yied. 
Putranto et al., 2012).

\section{Follicles Measurement}

At the end of the study, follicles found in the ovary were collected and divided into 3 groups based on their diameter. LFY or tertiary follicles and de Graff follicles (preovulatory) size varied between 5 to $8 \mathrm{~mm}$ or $>8 \mathrm{~mm}$, MFY or secondary follicles size varied between 1 to 5 $\mathrm{mm}$, SFY or primary follicles (primordial) sized $<1 \mathrm{~mm}$ (Putranto et al., 2012). Follicles were counted assisted with a hand counter for the number of follicles/hen unit, whereas their weights were measured by a digital balance.

\section{Statistical Analysis}

All data were analyzed using analysis of variance, and the significant results were further tested using Duncan Multiple Range Test (DMRT).

\section{RESULTS}

\section{Serum Steroid Hormone Metabolites Concen- tration}

Table 3 shows the effect of SA leaves on parameters of serum steroid hormone E2 metabolite concentration, serum steroid hormone P4 metabolite concentration, number and diameter of follicles, and egg production. SA leaves supplementation had a significant effect on serum steroid E2 hormone metabolite concentration (P $<0.01)$. It was shown that AK0 had significantly lower serum steroid hormone E2 metabolite concentration than AK1 and AK2. Then AK1 had significantly higher serum steroid hormone E2 metabolite concentration compared to AK2 and AK3 $(\mathrm{P}<0.01)$. Thus, the supplementation of $4 \%$ SA leaves powder resulted in the highest concentration of serum steroid hormone E2 metabolite $(3094 \mathrm{pg} / \mathrm{hen})$, followed by the level of 8 and $12 \%$ which were 1789 and $606 \mathrm{pg} / \mathrm{hen}$, respectively. In comparison to the control group, the concentration of serum steroid hormone E2 metabolite concentration of AK1 was 5.5-fold higher. Then, AK2 and AK3 serum steroid hormone E2 metabolite concentration were 1.8-fold and 1.1-fold higher, respectively, than AK0 as the control.

SA leaves powder supplementation had a significantly effect on serum steroid hormone progesterone $(\mathrm{P} 4)$ metabolite concentration $(\mathrm{P}<$ 0.05). This was shown that AK0 had a significantly lower serum steroid hormone P4 metabolite concentration than AK1. Then AK1 had a significantly higher serum steroid hormone P4 metabolite concentration compared to AK2 and AK3 $(\mathrm{P}<0.05)$. Thus, the supplementation of $4 \%$ SA leaves powder resulted in the highest concentration of serum steroid hormone $\mathrm{P} 4$ metabolite $(9.6 \mathrm{ng} / \mathrm{hen})$, followed by the level of 8 and $12 \%$ which were 2.5 and $1.5 \mathrm{ng} / \mathrm{hen}$ respectively. In comparison to the control group, the concentration of of AK1 was 14.5-fold higher. Although non significantly different, AK2 and AK3 serum steroid hormone P4 metabolite concentration were 3.7-fold and 2.2-fold higher, respectively, than AK0 as the control.

\section{Follicles Yield}

SA leaves powder supplementation had a significant effect on the number of medium follicle yield (MFY) $(\mathrm{P}<0.01)$, but it had no effect on large follicle yield (LFY) and small follicle yield (SMF). Figure 1 shows profile of kampung hen's follicles (LFY, MFY, and SFY) found in this study. It was shown that AK0 had a lower number of LFY compared to AK1, AK2, and AK3. Then AK1 had a higher number of LFY compared to AK2 and AK3. Thus, the supplementation of $4 \%$ SA leaves powder resulted in the highest number of LFY (23 follicles), followed by the level of 8 and $12 \%$ which were 19 and 17 follicles respectively. In comparison to the control group, LFY number of AK1 was 8 follicles higher. Then, AK2 and AK3 LFY numbers were 4 and 2 follicles higher, respectively, compared to AK0 as the control. Data in Table 3 was shown that AK0 had significantly lower number of MFY compared to AK2. AK2 had a significantly higher number of MFY compared to AK3 $(\mathrm{P}<0.01)$. Thus, the supplementation of $8 \%$ SA leaves powder resulted in the highest number of MFY (50 follicles), followed by the level of 4 and $12 \%$ which were 43 and 20 follicles, respectively. In comparison to the control group, MFY numbers of AK2 was 33 follicles higher. Although non significantly different, AK1 and AK3 MFY number were 26 and 3 follicles higher, respectively, compared to AK0 as the control. It was shown in Table 3, although statistically non-significant AK0 had higher number of SFY compared to AK1, AK2, and AK3. Then AK1 had a higher number of SFY compared to AK2 and AK3. No supplementation of SA leaves powder $(0 \%)$ tended to be resulted in the highest number of SFY (674 follicles) compared of all supplementation levels. SFY number of AK0 was 295 follicles tended to be 
higher than AK1, 305 and 353 follicles tended to be higher than AK2 and AK3, respectively. Most populated follicles found in form of SMF which was 674 follicles/hen and based on its diameter they were categorized as primary follicles (primordial).

SA leaves powder supplementation had no significant effect on the weight of follicles in kampung hens $(P>0.05)$. Although non significantly different, AK0 tended to be lighter compared to AK1. However, AK0 was tended to be heavier than AK2 and AK3 LFY. Then AK1 tended to be heavier compared to AK2 and AK3. Thus, the supplementation of $4 \%$ SA leaves powder tended to have resulted in the highest weight of LFY ( $29 \mathrm{~g} / \mathrm{hen})$, followed by the level of 8 and $12 \%$ which were $14 \mathrm{~g} / \mathrm{hen}$. In comparison to the control group, LFY weight of AK1 was $13.4 \mathrm{~g}$ heavier. However, LFY weight of $\mathrm{AK} 2$ and $\mathrm{AK} 3$ was 1.62 and $1.89 \mathrm{~g}$ tended to be lighter compared to AK0. The heaviest follicle weight was found in large LFY was $29 \mathrm{~g}$ and based on its diameter they were categorized as tertiary or preovulatory follicles.

\section{Egg Production}

Results in Table 3 show that SA leaves powder supplementation had no significant effect on total egg production in kampung hens ( $\mathrm{P}$ $>0.05)$. Although non-significantly different,

Table 3. Effect of S. androgynus Leaves Powder Supplementation on Indonesia Kampung Hens Reproductive Trait Parameters

\begin{tabular}{|c|c|c|c|c|}
\hline \multirow{2}{*}{ Parameters } & \multicolumn{4}{|c|}{ Level of Supplementation } \\
\hline & $\mathbf{A K O} \pm \mathrm{STD}$ & $\mathbf{A K 1} \pm \mathrm{STD}$ & $\mathrm{AK2} \pm \mathrm{STD}$ & $\mathbf{A K 3} \pm \mathbf{S T D}$ \\
\hline \multicolumn{5}{|c|}{ Serum Steroid Hormones Metabolites Concentration } \\
\hline E2 (ng/hen) & $564.040^{* *} \pm 9.49$ & $3093.650^{* *} \pm 167.00$ & $1789.370^{* *} \pm 37.40$ & $606.450^{* *} \pm 22.04$ \\
\hline P4 (pg/hen) & $0.663^{*} \pm 0.03$ & $9.583^{*} \pm 1.70$ & $2.484^{*} \pm 0.06$ & $1.484^{*} \pm 0.05$ \\
\hline \multicolumn{5}{|c|}{ Number of Follicles (follicles/hen) } \\
\hline LFY & $15 \pm 3.00$ & $23 \pm 0.89$ & $19 \pm 1.92$ & $17 \pm 3.21$ \\
\hline MFY & $17^{* *} \pm 2.41$ & $43^{* *} \pm 2.51$ & $50^{* *} \pm 6.63$ & $20^{* *} \pm 4.53$ \\
\hline SFY & $674 \pm 61.11$ & $379 \pm 24.46$ & $369 \pm 49.62$ & $321 \pm 47.01$ \\
\hline \multicolumn{5}{|c|}{ Weight of Follicles (g/hen) } \\
\hline LFY & $15.490 \pm 3.08$ & $28.893 \pm 0.40$ & $13.875 \pm 1.85$ & $13.600 \pm 2.52$ \\
\hline MFY & $0.533 \pm 0.07$ & $0.917 \pm 0.10$ & $0.517 \pm 0.01$ & $0.367 \pm 0.07$ \\
\hline SFY & $10.730 \pm 0.83$ & $11.950 \pm 0.38$ & $11.370 \pm 0.77$ & $9.680 \pm 0.99$ \\
\hline \multicolumn{5}{|c|}{ Egg Production (egg) } \\
\hline Total & $93 \pm 7.57$ & $89 \pm 7.46$ & $65 \pm 7.35$ & $23 \pm 4.06$ \\
\hline Individual & 21 & 19 & 17 & 12 \\
\hline \multicolumn{5}{|c|}{$\begin{array}{l}\text { Significant at } *(\mathrm{P}<0.05), * *(\mathrm{P}<0.01) ; \mathrm{AK} 0=\text { kampung hens were given a diet without } S \text {. adrogynus leaves powder (SALP } \\
\text { AK1 = kampung hens were given a diet with } 4 \% \text { SALP; AK2 = kampung hens were given a diet with } 8 \% \text { SALP; AK3 } \\
\text { kampung hens were given a diet with } 12 \% \text { SALP; E2 = hormone estradiol-17 } \beta \text { in ng/hen unit; } \mathrm{P} 4=\text { hormone progesterone } \\
\text { pg/hen unit; Number LFY = large follicle yield in follicles/hen unit; Number MFY = medium follicle yield in follicles/hen uni } \\
\text { Number SFY = small follicle yield in follicles/hen unit; Weight LFY = large follicle yield in } \mathrm{g} / \text { hen unit; Weight MFY = mediur } \\
\text { follicle yield in } \mathrm{g} / \text { hen unit; Weight SFY = small follicle yield in } \mathrm{g} / \text { hen unit; Total = total egg production in egg unit; Individual } \\
\text { highest individual egg production in egg unit }\end{array}$} \\
\hline
\end{tabular}


AK0 as control group tended had highest total egg production (93 egg/hen) compared to all supplemented groups (AK1, AK2, and AK3). Among supplemented kampung hen groups, AK1 tended had higher total egg production (89 eggs/hen) compared to AK2 and AK3 which were 65 and 23 eggs/hen, respectively. Thus, the supplementation of $4 \%$ SA leaves powder tended to be resulted in the highest total egg production/ hen compared to the level of 8 and $12 \%$ supplementation. Total egg production of AK0 was 4 eggs higher than AK1, 28 and 70 eggs higher than $\mathrm{AK} 2$ and $\mathrm{AK} 3$, respectively.

It was shown that AK0 as control tended had highest individual egg production (21 egg) compared to all supplemented groups (AK1, AK2, and AK3). Among supplemented kampung hen groups, AK1 tended had higher individual egg production (19 eggs) compared to AK2 and AK3 which were 17 and 12 eggs, respectively. The supplementation of $4 \% \mathrm{SA}$ leaves powder tended to be resulted in the highest individual egg production compared to the level of 8 and $12 \%$ supplementation. Individual egg production of AK0 was 3 eggs higher than AK1, 4 and 9 eggs higher than AK2 and AK3, respectively. It seems that high individual egg production in this latest study of Indonesia kampung hens correlates with total egg production.

\section{DISCUSSSION}

\section{Serum steroid hormone metabolites concen- tration}

The result showed that the supplementation of SA leaves dosed 4 and $8 \%$ for 56 days of duration increased serum steroid hormone E2 metabolite concentration. The increase of serum steroid hormone E2 metabolite concentration in supplemented kampung hens could reach from 1 until 5-fold higher compared to control group. This similar increase pattern agrees with the observation of Putranto et al. (2012), who found that SA leaves extract supplementation increased serum steroid hormone E2 concentration in Burgo chicken.

The average concentration of serum steroid hormone E2 metabolite of the control group was low. Putranto et al. (2012) stated that female chicken only synthesized steroid hormone by using their natural cholesterol in the cortex adrenal and liver. In contrast, the average concentration of serum steroid hormone E2 metabolite with supplemented SA leaves was higher than control. SA leaves supplementation might involve increasing process of the concentration of serum steroid hormone E2 metabolite in Indonesia kampung hens. According to Awaludin et al. (2020) and Hayati et al. (2016), the SA plant contains benzoic acid. Benzoic acid in the body can be converted into estradiol benzoate. Estradiol benzoate and other compounds such as androstan-17-one,3-ethyl-3-hydroxy-5 alpha represent 17-ketosteroid (Hayati et al., 2016) play a role in improving reproductive function such as estrogen steroid hormone development and stimulating follicle growth.

The higher concentration of serum steroid hormone E2 metabolite in this study reflected that Indonesia kampung hen produces more estrogen steroid hormone not only by using their cholesterol in the body. Ovary of aves species begins to develop and cause secretion of steroid hormones such as estradiol when the individual reached sexual maturity (Jamieson, 2007). Furthermore, the serum steroid hormone E2 metabolite will increase as the follicles developed. The previous study (Putranto et al., 2012) reported that the majority of estrogen is formed as estrone, E2, and estradiol-17 $\alpha$.

Supplementation of SA leaves powder treatment resulted from a similar profile on serum steroid hormone P4 metabolite concentration to serum steroid hormone E2 metabolite concentration in kampung hens. Serum steroid hormone P4 metabolite concentration in nonsupplemented kampung hens is tended to be lower than supplemented hens as the control. The increase of serum steroid hormone P4 metabolite concentration in supplemented kampung hens could reach from 2 until 14-fold higher compared to the control group. Hormone P4 is produced in the ovary of females (Jamieson, 2007). Its concentration is dynamically changes due to reproductive cycles of females such as during estrus and pregnancy in mammals (Putranto et al., 2007). Similar to serum steroid hormone E2 metabolite concentration mentioned earlier (Awaludin et al., 2020; Hayati et al., 2016), SA leaves supplementation may involve in the increasing process of the concentration of serum steroid hormone P4 metabolite. Cholesterol in the body as a basic component and benzoic acid content in SA plant as precursor to steroid hormone production (Putranto et al., 2012) contributed to their role function to develop more volume of serum steroid hormone P4 and also took the main role in ovulation stage. 
It could be assumed that there is another cause for this increase pattern of hormone P4 in this study (Putranto, unpublished data). Jamieson (2007) reported, amount of hormone P4 produced not only by the ovary of hens, however it is also caused by an additional amount of hormone P4 produced by preovulatory follicles which are ready to be ovulated. The higher concentration of serum steroid hormone P4 metabolite in this study is showing us that there is a connection to the number of LFY of sexually mature hens. Jamieson (2007) and Johnson (1990) reported that hormone $\mathrm{P} 4$ can be also produced by a corpus luteum of large size follicles. As we can see the number of large-size follicles of SA leaves supplemented kampung hens are more populated than non-supplemented hens.

The concentration of serum steroid hormone P4 metabolite in Indonesia kampung hens showed a positive correlation between the availability of additional hormone $\mathrm{P} 4$ produced by follicles that are ready to ovulate known as de Graff's follicles (Jamieson, 2007). The number of follicles that develop into de Graff's follicles is directly proportional to the concentration of serum steroid hormone $\mathrm{P} 4$ metabolite secreted by the ovum. Jamieson (2007) stated that the production of hormone P4 increases drastically controlled by luteinizing hormone (LH). Furthermore LH is induced by the form of cAMP because follicle formation approaches the time of ovulation.

It has been reported that there is a correlation between spontaneous and preovulatory ovulation due to the surge in hormone P4 during the ovulatory cycle in Japanese quail, ducks, layingtype chickens and turkeys (Liu et al., 2004). Spontaneous ovulation and oviposition in birds are caused by the role of the hormone system. In turkeys who received implanted hormone P4, egg production tended to be decreased (Liu et al., 2004), and quails can be stopped laying eggs for a short time (Tell et al., 1999).

\section{Follicles Yield}

The previous studies reported the average population of the follicle in kampung hens varied between 14 to 23 follicles per hen (Putri et al., 2013), and our study resulted in a population ranged between 15 to 23 follicles (Table 3 ). The population of follicles counted was large size follicles only (LFY). The growth and development of follicles is strongly influenced by many factors including lighting, stress, and nutrition
(Jamieson, 2007).

Most of follicles development activities in aves are occured in the inner cortex of ovary and it is different from mammals (Jamieson, 2007). The post primordial phase of chicken follicles is easy to observe and distinguish from stroma ovary tissue, a bonded grapes-like. In this study, the follicle counts are based on follicle size classification by previous reports (Putranto et al., 2012; Johnson, 1990). Follicles sized less than $1 \mathrm{~mm}$ were categorized as primary follicles (primordial), medium size or secondary follicles size were ranged from 1 to $5 \mathrm{~mm}$ and large size or tertiary follicles and de Graff follicles (preovulatory) size were ranged from 5 to $8 \mathrm{~mm}$ or $>8 \mathrm{~mm}$.

Even though supplementation of SA leaves powder in Indonesia kampung hens initiate a higher average number of large and medium-size follicles compared to non- supplemented hens, it's significantly affected on medium-size follicles only. On contrary, the average number of small-size follicles in supplemented kampung hens is tended to be lower than nonsupplemented hens as the control group. In the case of small-size follicles, a previous report by Putranto et al. (2012) assumed SA leaves powder tends to reduce the digestibility of crude fat. Presumably, there is an inhibitory effect contained in SA leaves on the synthesis of liquid in bile which forces a secretion of liquid to increase. The higher secretion of bile as a result of decreased crude fat digestibility indicates a decreasing absorption of fat and other fat components and fat derivatives such as decreased cholesterol, LDL, HDL, and triglycerides. We assumed that the decreasing of acid in bile caused a decreasing crude fat digestibility and causes a low-fat absorption.

The effect of cholesterol absorption inhibition leads to an obstruction of ovaries to synthesis estrogen and this will inhibit the follicle formation process. The ovaries can produce the hormone estrogen which has an important role during the egg formation process (Johnson, 1990), and the concentration of hormone estrogen increases along with the development of ovarian follicles. Therefore, this caused an inhibitory effect on small-size follicles development especially from the pre-heararchal follicles phase to the preovulatory and ovulatory follicles phase. It is also reflected in the number of medium-size and large-size follicles of supplemented kampung hens compared to non-supplemented hens in this 
study.

The weight of follicles in this study is assumed has a correlation with follicle size, follicle numbers and SA leaves powder supplementation level. In total, the average weight of large-size and medium-size follicles in supplemented kampung hens is higher than non-supplemented hens. It is correlated to the number or follicle population. A higher population of large and mediumsize follicles contribute to a heavier total weight of follicles. However in small-size follicles data, follicle population does not contribute to a heavier weight. The weight of non-supplemented kampung hens follicle is lower than supplemented hens. We assumed that small-size follicles number of non- supplemented kampung hens is more populated by smaller size follicles compared to supplemented hens. It caused a higher number of follicles with lighter weight.

Naturally, a sexually matured hen has approximately 3000 to 4000 follicles in its ovary (Jamieson, 2007). The total number of follicles in this study was approximately only 11 to $17 \%$ of normally populated follicles in the mature hen. However, this study result is higher than populated follicles in Burgo chicken (Putranto et al., 2012). It seems that chicken body weight and body size are related to the number of follicles produced. It agrees with Soenarsih and Hoda (2019) and Mariandayani et al. (2013) study reports which stated that body weight and body size of kampung chicken became the main cause of this problem. Burgo hen's body size is smaller than Indonesia kampung hen in common and bigger than the wild red forest chicken (Putranto et al., 2012). Furthermore, we assumed many primary follicles (primordial) and post-ovulatory follicles in this study probably were in nano size and unseen by a usual visual count.

\section{Eggs Production}

The total egg production of kampung hens in this study varied between 23 to 93 eggs/group or averaged between 2,3 to $9,3 \mathrm{egg} / \mathrm{hen}$ during 56 days, specifically about 2.3 to 8.9 eggs/hen for kampung hens with supplemented SA leaves powder. When we assumed its production in a year, probably maximum of 53 to 56 eggs can be produced by kampung hens in this study. Probably the individual sexual maturity stage or status has become the main cause of egg production (Trisiwi 2017; Mariandayani et al., 2013).

Later, Indonesia kampung hen's total egg production in this study is lower than some re- cent reports. A recent study (Trisiwi 2017) reported that Indonesia kampung hens reared traditionally or under non-intensive management in a rural area could produce about 40 to 45 eggs/hen/ year. According to Mariandayani et al. (2013), the total egg production of kampung hens reared intensively could reach about 150 eggs/hen/year. This difference in total egg production is mainly caused by during egg formation process, a sufficient volume of hormones is required to stimulate ovary to develop follicles (Putranto et al., 2012). There is a possibility of serum steroid hormone P4 metabolite concentration affected by this lower egg production. Research reports showed that implanted hormone P4 caused decreasing egg production in turkey and the occurrence of stopping laying eggs in quails (Tell et al., 1999). In addition, Etches (1996) stated that hypothalamus secretes gonadotropin hormones, identified as FSH and LH which play a role as a regulator in ovarian function including follicular growth until its ready to be ovulated.

Data in Table 3 shown us about Indonesia kampung hens total egg production and individual egg production. In the control group hens, its average of total egg production and individual egg production is higher compared to supplemented kampung hens. It seems that SA leaves powder supplementation did not affect the average of total egg production and individual egg production. Agrees to Trisiwi (2017) report, the researcher believed the individual sexual maturity stage or status has become a main cause of this matter.

We assumed some of kampung hens in the control group reach an earlier pullet stage or early preovulatory stage and more ready to ovulate compared to other hens in this study. Based on the study results, the control group kampung hens has a lower population of secondary and tertiary follicles. Probably it is because hens in the control group have already ovulated more follicles than other hens, hereafter they delivered more eggs earlier than other hens.

Awaludin et al. (2020) and Hayati et al. (2016) stated benzoic acid compound in SA plant when its digested in the body, those benzoic acid will be converted into estradiol-17 $\beta$ benzoate which can improve the reproduction function and stimulates follicles growth. This mechanism can lead chickens potentially able to produce higher total egg production, individual egg production, and more efficient.

Another consideration is the body size of 
the sub-species. Body weight was measured to predict the relationship between body weight and the number of follicles and egg production. It seems that the body size is related to the number of follicles and egg produced. Added by Putranto et al. (2012), Indonesia kampung chicken has a smaller body size compared to broiler and layer. With its small size and compact body, it may cause the number of egg production of Indonesia kampung hen is less populated than a layer.

\section{CONCLUSION}

The 4\% level supplementation of SA leaves in Indonesia kampung hen feed increased serum steroid hormone E2 metabolite and serum steroid hormone $\mathrm{P} 4$ metabolite concentration, number and weight of follicles of medium size follicles, and it showed the best results. The role of precursor contained in SA leaves powder detected on Indonesia kampung hen's reproductive traits.

\section{ACKNOWLEDGEMENTS}

This research fully supported by the Universitas Bengkulu Indonesia, through the Percepatan Guru Besar Research Grant with contract number 2074/UN30.15/PG/2020 dated on 23rd of June, 2020. We thank to Research and Community Service Agency (LPPM) Universitas Bengkulu Indonesia, Laboratory of Animal Science, Department of Animal Science, Faculty of Agriculture Universitas Bengkulu Indonesia, and students who assisted researchers at Commercial Zone and Animal Laboratory (Juan R Sumarna, Alven Syahril Muslim and Nida F Aziz).

\section{REFERENCES}

Abou-Elkhair, R., S. Selim and E. Hussein. 2018. Effect of supplementing layer hen diet with phytogenic feed additives on laying performance, egg quality, egg lipid peroxidation and blood biochemical constituents. Anim. Nutr. 4: 398-400.

Awaludin, K., D. Maulianawati, W. Manalu, Andriyanto, R. Septiana, A. Arfandi and A. Lalang. 2020. Phytochemical screening and toxicity of ethanol extract of Sauropus androgynus. Biodiversitas 21: 2966-2970.

Ding, Y., L. Zeng, R. Li, Q. Chen, B. Zhou, Q. Chen, P.L. Cheng, W. Yutao, J. Zheng, Z. Yang and F. Zhang. 2017. The Chinese pre- scription lianhuaqingwen capsule exerts anti -influenza activity through the inhibition of viral propagation and impacts immune function. BMC Complement Altern. Med. 17 (130):1-11.

Etches, R.J. 1996. Reproduction in Poultry. University Press. Cambridge UK.

Habteslasie, H.A., M.R. Araya and K.D.A Arik. 2019. Qualitative morphometeric characterization of indigenous chicken of Gash-Barka region in Eritrea. J. Agric. Vet. Sci. 20: 89105.

Hayati, A., E.L. Arumingtyas, S. Indriyani and L. Hakim. 2016. Local knowledge of katuk (Sauropus androgynus (L.) Merr) in East Java, Indonesia. IJCPR. 7: 210-215.

Janczak, A.M., P. Torjesen and S. Rettenbacher. 2009. Environmental effects on steroid hormone concentrations in laying hens' eggs. Acta Agr. Scan. A. 59: 80-84.

Jamieson, B.G.M. 2007. Reproductive Biology and Phylogeny of Birds. Volume 6A of series: Phylogeny, Morphology, Hormones, Fertilization. Science Publishers. St. Lucia Queensland Australia.

Johnson, A.L. 1990. Steroidogenesis and actions of steroids in the hen ovary. Poultry Biol. 2: 319-346.

Letis, Z.M., A. Suprayogi and D.R. Ekastuti. 2017. Suplementation of various preparations katuk leaves in feed causing a decrease of abdominal fat, fat and cholesterol levels to carcass of broiler chickens. J. Veteriner. 18: 461-468.

Liu, Z.G., C.Z. Lei and J. Luo. 2004. Genetic variability of mtDNA sequences in Chinese native chicken breeds. Asian-Australas. J. Anim. Sci. 17: 903-920.

Mariandayani, H.N., D.D. Solihin, S. Sulandari and C. Sumantri. 2013. Phenotyphic variation and genetic estimation of local and broiler chicken by using morphology analysis. J. Veteriner. 14: 475-484.

Navara, K.J. 2013. The role of steroid hormones in the adjustment of primary sex ratio in birds: Compiling the pieces of the puzzle. Integr. Comp. Biol. 53: 923-937.

Nurmeiliasari, Y. Fenita, U. Santoso, Kususiyah and A. Kusnandar. 2020. Efficacy of medicinal plants on production performance and reproductive characteristics of laying hens. Jurnal Agripet. 20: 38-46.

Putranto, H.D., S. Kusuda, K. Inagaki, G. Kumagai, R. Ishii-Tamura, Y. Uziie and O. 
Doi. 2007. Ovarian activity and pregnancy in the Siberian tiger, Panthera tigris altaica, assessed by fecal gonadal steroid hormones analyses. J. Vet. Med. Sci. 69: 569-571.

Putranto, H.D., J. Setianto, U. Santoso, Warnoto, Nurmeliasari and A. Zueni. 2012. Estradiol$17 \beta$ hormone concentration and follicles number in exotic burgo chicken supplemented by Sauropus androgynus leaves extract. Biodiversitas 13:1-6.

Putri, Y., C.N. Thasmi, M. Adam and Nurliana. 2013. The effect of dietary nonfermented and fermented soybean waste by Aspergillus niger on amount of follicle of Gallus domesticus. J. Medika Veterinaria. 7: 75-78.

Reddy, I.J., C.G. David and S.S. Raju. 2006. Chemical control of prolactin secretion and it's effect on pause days, egg production and steroid hormone concentration in girirani birds. Int. J. Poult. Sci. 5: 685-692.

Santoso, U. 2018. The usefullness of Sauropus androgynus leaf as a feed supplement for poultry. 1. Its effect on chicken performances. J. Sain Peternak. Indones. 13:151-156.

Soenarsih, S. and A. Hoda. 2019. Community local knowledge on chicken productivity and phenotypic to support community food security in Ternate. Jurnal Ilmu Ternak. 19: 20-27.

Sulfiar, A.E.T., M.A. Pagala and L. Malesi. 2020. Performance of broiler chicken production that given leaf flour katuk (Saurapus androginus) with different levels. Ind. J. Anim. Agric. Sci. 2: 5-10.

Teinlek, P., K. Siripattarapravat and C. Tirawattanawanich. 2018. Genetic diversity analysis of Thai indigenous chickens based on complete sequences of mitochondrial DNA D-loop region. Asian-Australas. J. Anim. Sci. 31: 804-811.

Tell, L., A. Shukla, L. Munson, S. Thosar, P. Kass, R. Stanton, M. Needham and B. Lasley. 1999. A comparison of the effects of slow release, injectable levenorgestrel and depot medroxyprogesterone acetate on egg production in Japanese quail (Coturnix coturnix japonica). J. Avian Med. Surg. 13: 23-31.

Trisiwi, H.F. 2017. The effect of dietary protein levels in growing period on performance at onset of lay of crossbred hens between cockerel native chickens and commercial laying hens. Jurnal Ilmu dan Teknologi Hasil Ternak 12: 61-68. 